\title{
The Completion of the Church Roof of San Antonio de Valero
}

\section{Introduction}

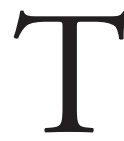

EXAS HISTORIANS, particularly those interested in the architectural history of the Spanish missions of Texas, have long known of a plan in the Bexar Archives for the construction of the roof of a colonial or Mexican-period church. The church for which this plan had been drawn, however, has remained unidentified. Architects who examined the plan during the Depression-era recovery projects in Texas in the I930s suggested that it was for the mission church of Refugio, Texas, between Corpus Christi and Victoria.

In a recent excellent article on the construction of the parish church in San Antonio, Adán Benavides published the plan for the first time, with a translation of its notations. ${ }^{\mathrm{I}} \mathrm{I}$ enjoyed reading through the detailed captions of the plan once again - but this time they struck me as similar to another document I had seen recently. I had been researching the early nineteenthcentury architectural history of the buildings of the mission of San Antonio

I. Adán Benavides, "Sacred Space, Profane Reality: The Politics of Building a Church in Eighteenth-Century Texas", Southwestern Historical Quarterly, vol. I07, no. I, 2003, pp. I-33; Juan Ygnacio de Arrambide, captain of the Compañía Volante, to commandant general Second Brigade Bernardo Bonavia, April 25, I8 Io, Austin, University of Texas at Austin-Center for American History-Bexar Archives microfilm (ВАм), roll 44, frames 953-955v; Juan Diego Veloz, Juan de Dios Cortez y José Cayetano del Valle to Juan Ygnacio de Arrambide, April 25, i 8 io, BAM, roll I 68 , frame 802 . 
de Valero, better known as the Alamo, for the last several years, when time allowed. Perhaps a year earlier I had noticed a listing in the calendar of the Bexar Archives for a document of I8 Io about "the estimate for the completion of the construction of cannon for Valero mission." ${ }^{2}$ This was potentially interesting - if it described the construction of a cannon position at Valero, it would suggest that some of the fortifications at the Alamo battle of I 836 had been built as much as 26 years earlier. I took a quick look at the document, and it was not for the construction of cannon at Valero, but instead was an estimate for the cost of the materials to complete the cañon of the Valero church. That is, it was an estimate for the building of a roof over the nave and transepts of the unfinished church building, a virtually unknown project that itself was apparently never carried out.

Reading Benavides's article a year later, and looking at the unidentified roof plan for the first time in several years, I immediately recalled that the estimate for finishing the roof at Valero that I had seen the year before had listed several of the same parts as in the roof plan notations, especially the unfamiliar term gualdras, large supporting beams or joists. As I thought about it, I realized that the measurements given for the church on the plan matched the same dimensions of the Valero church fairly closely — certainly closely enough to encourage the suspicion I began to entertain, that this plan had been prepared to accompany the I8ro estimate of roof construction for the Valero church.

I went back to the Bexar Archives microfilm and made copies of both the plan and the r8 10 estimate, and compared them. The handwriting was the same - whoever wrote up the estimate also annotated the plan. The parts listed on the plan were also listed in the estimate. Finally, comparing the sizes given on the plan with the actual dimensions of the Valero church showed that they were the same within a few inches.

The estimate does not mention an accompanying plan, but the similarities between the two documents, and between the plan dimensions and those of the church at Valero, leave no doubt that the plan was drawn as part of the estimate. Looking through subsequent correspondence in I8IO, I was able to locate a letter that specified the reason why the old mission building was to be completed: not to use as the church of the Barrio del Alamo, the old neighborhood of the mission of San Antonio de Valero, but to serve as the almacén de artilleria, the artillery storehouse, for the military units stationed at San

2. BAM, calendar, roll 44, entry for document beginning frame 953 . 
Antonio de Bexar. I have yet to find documents that indicate that the project was ever carried out (fig. I).

The two documents, now associated, together tell us much more about the project, the intended results, and the condition of the Valero church, than either document did alone. In order to give the reader an appreciation of this, I will outline the architectural historical context within which these two documents were prepared. Then I will use the two documents to evaluate what they tell us about the architectural condition of the Valero church, and what the intended roof was to have looked like.

\section{The Valero Church}

The long effort to build the church of Valero was a complex process, and needs not to concern us here. ${ }^{3}$ Two inventories of Valero made in 1772 and 1793 contain the most informative descriptions of the church during the colonial period. ${ }^{4}$ The 1772 inventory remarked that the church was being built using the "Tuscan", or Etruscan, order, a very simple decorative order taken from the Doric, ${ }^{5}$ which in this case meant a very plain, simple style of construction, much like that used to build Purísima Concepción de Acuña, another of the missions of San Antonio. ${ }^{6}$ The building was transepted, and the inventory said that it was 35 varas $(29.3 \mathrm{~m}=96 \mathrm{feet})$ long and nine varas $(7.5 \mathrm{~m}=24.7 \mathrm{feet})$ wide. The façade was nine varas, or about $7.6 \mathrm{~m}$ (25 feet), high:

3. My study, The Alamo: Mission to Fortress, will present the architectural history of the mission of San Antonio de Valero in detail.

4. Fray Juan José Sáenz de Gumiel, Inventory of the Mission San Antonio de Valero: 1772, translated by Benedict Leutenegger, Austin, Texas Historical Commission, Office of the Texas State Archeologist, Special Report, I977, vol. 23, p. 7; Fray José Francisco López, "Ymbentario de las existencias q[u] e hay hoy dia 23 de Abril de I793, en la Mis[ion] de San Antonio Valero", San Antonio, Texas, Our Lady of the Lake University, Old Spanish Missions Historical Research Library (OSMHRL), Celaya microfilm collection, I793, microfilm roll 4, frame 5808 .

5. Secretaría del Patrimonio Nacional (ed.), Vocabulario arquitectónico ilustrado, Mexico City, Secretaría del Patrimonio Nacional, I975, p. 426: Tuscan was a "Roman architectural order, taken from the Etruscans, who were inspired by the Greek Doric. Its resemblance to it [the Doric] is great, although [Tuscan is] of greater simplicity. It was much used during the Renaissance".

6. See James E. Ivey, Of Various Magnificence: An Architectural History of the Missions of San Antonio, Texas, manuscript in the files of San Antonio Missions National Historical Park, San Antonio, Texas, for a complete architectural history of the San Antonio Missions. 
[...] las bobedas han de ser aristas; tiene ya concluida la del presbiterio. Ytt[em] los quatro arcos torales de piedra labrada a fundamentis para rezibir al zimborio.

Ytt $[\mathrm{em}]$ otros dos arcos acabados en el cañon, y el de el coro alto puesto en disposicion de salmeres, faltale que hazer un arco de los de el cańon. ${ }^{7}$

[...] the vaults are to be groined; that of the sanctuary has been completed.

Item: the four main arches of carved stone [at the crossing of the transepts] as foundation to receive the dome.

Item: another two arches finished in the nave, and that of the elevated choir loft has its springers in place; not yet made is one arch of those of the nave.

In I793, the inventory said that the church was 34.25 varas, or $28.6 \mathrm{~m}$ (93.9I feet), long, and nine varas wide, but the description of the building was almost the same:

[...] las vobedas [...] de cañon [...] tienen los arcos en estado de luneta. La de el Prebisterio [sic] esta concluida con su arco toral, y los otros 3 cerrados, y en estado de recivir el cimborrio. Otros dos arcos acabados, en el cańon de la Yglecia, el de el coro vajo puesto en capitel con sus 2 salmeres, y de primera, y segunda. Falta uno de los arcos de $\mathrm{d}[\mathrm{ic}]$ ho cańon quedando concluida. ${ }^{8}$

$[\ldots]$ the vaults [...] of the nave [...] have the arches in the form of a lunette [semicircle; an arco de media punta]. That of the sanctuary is finished, with its main arch, and the other three are closed, and in condition to receive the dome. Another two arches are finished in the nave of the church, that below the choir loft is placed on its capital with its two springer stones and the first and second [stones above that]. It lacks one of the arches of the said nave in order to be able to be finished.

As of 1772 , then, in addition to the ribs of the arco toral at the crossing of the nave and transepts, two of the three ribs that were to support the vault of the nave were in place. The missing rib was the westernmost one, that was to be over the choir loft. The arch to support the choir loft itself had been begun: the springers were in place on top of the capitals of the pilasters. These were the first stones set into the wall with an angled upper face on which the stones of the arch would be

7. Sáenz de Gumiel, Valero: 1772 , p. 7. All translations in this article are by the author.

8. López, "Ymbentario... I 7933 ", microfilm roll 4, frame 5808. The actual length is $29.9 \mathrm{~m}$ (98. I 2 feet), or $64.7 \mathrm{~cm}$ (2.I 2 feet) longer than the 1772 measurement, and I.3 $\mathrm{m}$ (4.2 I feet) longer than the 1793 measurement. The actual width is $7.7 \mathrm{~m}$ ( $25.25 \mathrm{feet})$ from wall face to wall face, about $17.8 \mathrm{~cm}$ ( 7 inches) wider than the 1772 and 1793 measurements. 
THE COMPLETION OF THE CHURCH ROOF

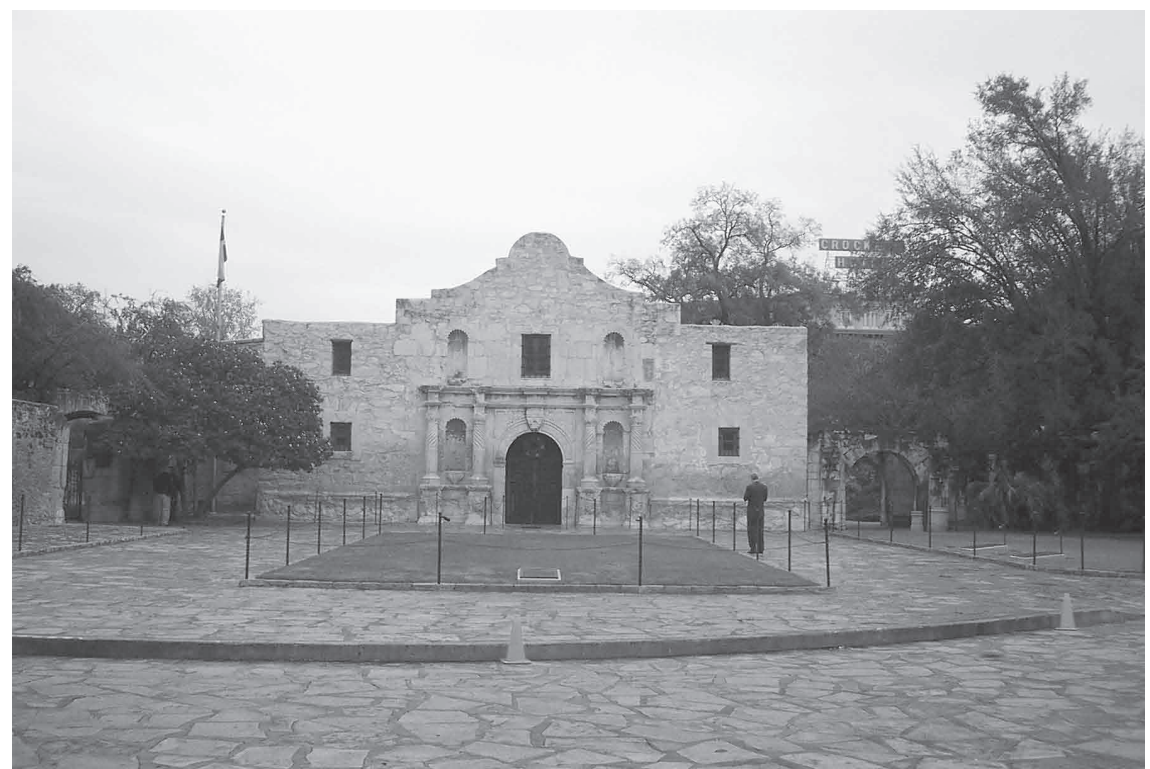

I. The mission church of San Antonio de Valero (the Alamo) today. The distinctive shape of the top of the façade is the result of the construction of a stone gable in I 850 to cover the end of the wooden roof built over the roofless building in that year by the U. S. Army so that it could be used as a military storehouse. Photograph by the author.

placed. The 1793 inventory described the first two dovelas, voussoirs, beyond the springers of the choir arch as being in place as well - since there is no evidence for any construction on the church after 1772 , these were probably also in place at the time of the December, 1772 inventory (fig. 2).

The surviving fabric of the church indicates that the ribs were one vara, or $82.3 \mathrm{~cm}$ ( $2.7 \mathrm{feet}$ ), wide. The lowest parts of the arches of the ribs where they spring from the walls are still in place, and are flat-sided, without shoulders or decorative carving on the sides. This suggests that the vaulting was to rest on the upper surfaces, the extradós, of these ribs, rather than on shoulders partway up the sides of the ribs, or that the ribs were not to support the vaults directly, but instead acted as stabilizing dividers between sections of the vaulting.

The Franciscans intended the ceiling of the church to be a groined vault. The present vault of Valero as it was finished in concrete in the early twentieth century is a barrel vault, a series of single curved, cylindrical sections covering the nave, transepts and sanctuary. The concrete vault does have a groined sec- 
tion in the center of the intersection of the nave and transepts; in the original plan for Valero, this area was intended to be an opening up into the dome to be placed over the crossing.

There are two choices in how one builds this sort of vaulting. The first method is to make the radius of curvature for the lateral vaults equal to the radius of curvature of the main vault; technically, the curvatures of the intersecting cylindrical vaults of a groined vault should be equal. However, when the length of the bay is so much shorter than the width, as at Valero, this results in a groined vault where the curvatures of the sections of the cylinders of each vault actually built are so shallow that much of their force would be directed sideways at the tops of the church walls. The buttressing included in the plan of Valero was insufficient to counteract these forces. The Franciscans approved a similar vaulting at the church of San Francisco in Zacatecas - and the vaulting pushed the wall tops sideways until the central areas of the vaults fell in, rendering the church both unusable and unrepairable without a virtually complete reconstruction that never happened.

The second method is to use lateral vaults with a smaller radius of curvature. If the spring points for these smaller lateral cylinders are placed at the same height as the spring point for the main vault, the lateral vault sections do not reach as high as the longitudinal vault sections, so that the intersections of the two do not reach the peak of the curvature of the main vault section. This is called a lunette vault. The mission church at San José y San Miguel de Aguayo has this sort of roof. Alternatively, the spring points for the lateral vault sections could be raised so that the peak of the curve of the vault was at the same height as the peak of the longitudinal vault section. This would make something like a groined vault, with the vaults actually intersecting at their peaks - but when the bay is shorter than it is wide, the smaller radius of the transverse vaults pulls the lateral vaulting up the ribs so that the lower parts of the ribs are exposed near the walls.

It is clear from the repeated use of the term bovedas aristas in the 1772 and 1793 inventories to describe the vault design in the church, the sacristy, and the ground-floor rooms in the two tower bases that the second choice is what the Franciscans had in mind for Valero. ${ }^{9}$ The areas of vaulting that were built and still survive today, the ceilings of the ground-floor rooms of the bell-

9. Sáenz de Gumiel, Valero: 1772, pp. 7 and 8; López, "Ymbentario... I793", microfilm roll 4, frame 5808 . 


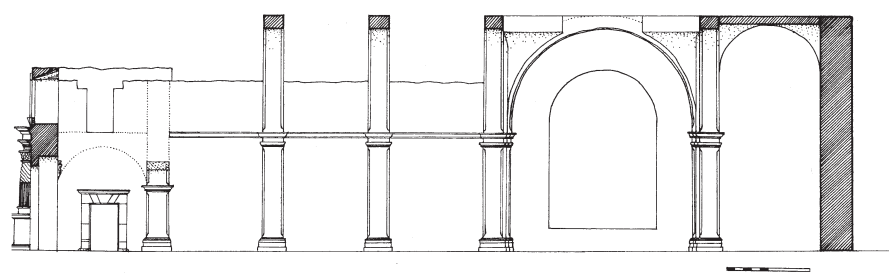

2. Section down the length of the Valero church, showing its condition when construction stopped sometime before 1793 . The vault over the apse had been completed, the ribs and pendentives to support the dome over the crossing of the transepts had been built, and two of the three ribs for the nave vaults had been finished. The rib to support the choir loft was under construction when work stopped. Drawing by the author.

towers and the vaulted ceiling of the sacristy, are groined vaults rather than lunette vaults.

The side walls of the church stopped at the height where the spring-line of the transverse vaults of each bay would have begun. The arches above this point in the side walls that would have anchored the ends of the transverse vaults were never built in the nave. The walls of the transepts and sanctuary stood about seven feet higher than the nave walls, and the vaulting of the sanctuary had been built within these side walls. It is likely that the arches to support the ends of the vaults in the transepts had also been built. However, the ribs and the wall tops of the transepts and sanctuary were demolished by colonel Domingo de Ugartechea of the Mexican army during the fortification of the mission in the Siege of Bexar in late I835-Samuel Maverick, a prisoner in San Antonio at the time, described how the troops "threw down the arches [ribs] of the church [...] in order to make an inclined plane to haul cannon on top of the church." Io No trace of the vaulting over the apse or the wall arches for the ends of the vaults survives, or any of the provisions for the finishing of the vaulting over the transepts. The beginnings of arches built into the end walls of the transepts are still visible on the surviving transept walls, but these appear to have been decorative rather than structural. The loss of the fabric of the side walls of the transepts and apse makes it more difficult to work out the intent of the architects for the final appearance of the building.

Io. Samuel Maverick to Captain S. M. Howe, July 3, I 847, in Rena Maverick Green, Memoirs of Mary A. Maverick, San Antonio, Alamo Printing Co., I92 I, pp. I33-34. 
The choir loft supporting vault was probably intended to be groined as well. Physical evidence in the form of a mass of rubble fill cemented in place about ten feet above the floor in the northwest corner of the church interior, and an arched scar on the interior of the façade wall as shown in Edward Everett's drawing, "Interior of the Alamo", made in I 847 , indicates that by 1772 the vault under the choir loft was under construction at the same time as the choir supporting rib. It was clearly to be vaulted with the same groined appearance as the main ceiling. The longitudinal section of the vault could not be a semicircular vault like that for the roof, because this would not fit below the choir loft floor level and above the capitals of the choir pilasters - the curve of the longitudinal vault had to be shallower than the curve of the roof vaulting. In other words, the longitudinal portion of the vaulting had to be a segmental vault rather than a semicircular one, while the lateral vault sections could be of the same curvature as the ceiling vault lateral sections, and in fact would have exactly replicated the curvature of the groined vaults still surviving in the two lateral rooms in the bases of the bell towers. The springers of the choir loft supporting vault survived until the construction of the new concrete vault in the I930s, and clearly had the steeper angle required for a segmental vault.

The presence of the wall scars and cemented fill traces indicate that in 1772 a portion of the vaulting next to the front wall of the church was under construction. This shows that scaffolding and centering for both the choir loft rib and the entire choir loft were in place, in order to support the weight of the voussoirs of the arch and vault until they were closed and became self-supporting. Everett stood on the top of the apse wall and drew a view down the nave, in which the springers of the vault ribs can be seen at the tops of the pilasters. Although the ribs had all been removed by colonel Ugartechea, the "salmeres, y de primera, y segunda" were still in place above most of the visible pilasters, including the one nearest the front that was to hold up the choir loft. However, there are no pilasters above the springer stones of the choir loft arch, making it clear that the ceiling rib here had not been begun. Most of these lowest parts of the ribs are still in place today at the bases of the ribs of the modern concrete vault, just as they were shown by Everett in $1847{ }^{11}$

Everett showed the wall above the floor level of the second story room in the south bell tower to be absent - it appears that this section of nave wall, the

I I. George Nelson, The Alamo: An Illustrated History, second edition, Uvalde, Texas, Aldine Books, 1998, p. 67; Richard E. Alhborn, The San Antonio Missions: Edward Everett and the American Occupation, I847, Fort Worth, Amon Carter Museum of Western Art, I985, p. I2, pl. 2. 
doorway into this room, and the cornice along the springline of the wall near the choir pilaster had yet not been built when construction stopped, but were finished on the north side, including the carved stone doorway into the north bell tower room that was to have been the antecoro, the vestry before the choir loft. However, the lintels of both the door from the access stairs to the antecoro, and from the antecoro to the choir loft itself were not put in place.

At the front of the church, the baptistry was in the base of one of the bell towers, with its groined vaulted ceiling - probably the north one, as at Purísima Concepción. The room in the base of the other bell tower also had its vault, "encima de las quales se hallan ya los arranques de dos torres" (above which [rooms] were the lower parts of the two bell towers). ${ }^{12}$ The inventory did not mention the doorway on the north wall of the north bell tower that would have been the access from the outside to the antecoro, mentioned above. It was probably to have been reached by a stone stairway up the north exterior wall of the north bell tower. ${ }^{13}$

The i8ro estimate for the completion of the church roof, and its accompanying plan, gives a few more details of what was built on the incomplete structure, not mentioned in the inventories. This, in context with the earlier descriptions and a careful analysis of the fabric today and as shown in early drawings and photographs, allows us a better understanding of both the intended design and the actual level of completion of the building when work stopped about 1772 .

\section{After Secularization}

The Compañía Volante del Alamo de San Carlos de Parras arrived in San Antonio on December 29, I802, and governor Juan de Elguezábal posted them to the abandoned buildings of the now-empty mission of San Antonio de Valero. ${ }^{14}$ This company gave its name to the old mission, and soon people were calling the place "the Alamo". The sacristy of the mission church, in use for services while the church itself was unfinished, became the church for the Barrio de Valero, and for the Compañía Volante.

I 2. Sáenz de Gumiel, Valero: 1772, p. 7; López, "Ymbentario... I793", microfilm roll 4, frame 5808 .

I3. W. Eugene George, "Mission San Antonio de Valero (The Alamo)", San Antonio, Bexar County, Texas, Historic American Buildings Survey, U. S. Department of the Interior, National Park Service, I96I, sheet I 2.

I4. Juan Elguezábal, Dec. 29, I 802, BAM, 30, pp. 947-949. 


\section{Military Uses of the Mission Buildings}

In I805, governor Antonio Cordero decided to establish a military hospital in San Antonio, and the friary building of the old mission of San Antonio de Valero, part of which was in use as quarters for the officers of the Compañía Volante, was chosen to house this hospital. ${ }^{\text {Is }}$ It was placed in one of the unused rooms in the west wing of the friary, but eventually took over the entire west wing, while the other wings fell or were robbed of stone for construction in the area. By 1809 the hospital building had deteriorated to the point that its flat roof was rotted and leaking, and several walls were beginning to collapse. The governor decided to carry out a major repair of the friary building in use as the hospital. ${ }^{16}$ This was one of a number of expenditures on military construction across the province of Texas during these years before the beginning of the struggle for Independance in I8Io. The proposal to roof the church of Valero was another of these projects.

\section{Repairing the Friary-Hospital}

The major part of the repair effort on the hospital would be to construct a new roof on the building. Preparation for this project included a detailed examination of the friary building, and the preparation of a materials list and cost estimate for the project. The estimate of the materials and cost to repair and re-roof the friary building was prepared on May 5, 1809, by the architects Juan Diego Veloz, Juan de Dios Cortez, and Francisco Barrera. This work is of interest here, because two of the three architects who worked on the friary hospital project, Veloz and Cortez, submitted the estimate to finish the roof of the church a year later, and the construction of the hospital roof had similarities to the work proposed for the church roof. The work on the hospital began on May 17, 1809, and was completed by May 2, 1810. ${ }^{17}$ We know what the friary roof structure looked like, and the repair work essentially replaced the original roof, so we know what roof structure the repair project was to accomplish.

I 5. Governor Antonio Cordero, October I9, I805, BAM, 33, p. 782.

I6. Mariano Varela, comisionado del Hospital, to governor Manuel de Salcedo, May 5, I809, BAM, 4I, pp. 207-208.

17. Bernardo Bonavia to Nemesio Salcedo, May 2, i 8 Iо, Bam, 45, pp. 36-37. 
The similarities and differences between the friary re-roofing estimate and the estimate for the Valero church can tell us something about the similarities and differences between the intended roofs.

Instead of a plan drawing of the work, as used in the estimate for the completion of the church roof, the estimate for the 1809 repair of the hospital in the friary building began with a statement of the work needing to be done, including the total length, width, and height of parapets needing repair, the total area of roof surface in need of replacement, and the total area of wall surface that needed repointing and recoating with lime mortar. It listed the number of roof vigas needing to be replaced, and a brief description of other work, such as the replacement of floors in specific areas and the rebuilding of specific walls that were falling or were about to fall. This was followed by an estimate of materials needed to do the work, and their cost, just as in the estimate for the completion of the church roof a year later. These are the materials included in the friary hospital estimate:

Por 350 carretadas de Piedra puestas al pie de la obra y traida desde la cantera mui immediata á I p[es]o

Por 355 carretadas de tierra blanca para hacer lodo puestas en dicho paraxe á 4 rr[eale]s $162.4^{18}$

Por 2000 fanegas de Cal para ormigones las Azoteas Enjarres, y Sarpeos las Paredes por fuera y dentro, y blanquear las dichas á $6 \mathrm{rr}$ [eale]s fanega puestta en la obra I 500

Por 820 Carretadas de Arena para hacer mescla Regulada á 4 fanegas cada carreta y 4 rr[eale]s cada una de estas 410

Por 520 Morillos para Reponer la [s] vigas[s] de los techos y Soleras á I peso 520

Por I6995 Tabletas á 30 p[eso]s el millar $5 \mathrm{IO}$

Por 73 Canales de madera á I peso

Por 600 Peonadas de Maestros á I 2 rr[eale]s cada uno 900

Por 3600 Peonadas de Mosos á 3 rr[eale]s I 350

Por 12 Cueros de Res para hacer correas y amarrar los Andamios á $6 \mathrm{rr}[\mathrm{eale}] \mathrm{s}$

I 8. This is an error: the amount should be 177 pesos 4 reales, not 162 pesos 4 reales. The amount given is correct for a quantity of 325 carretadas, which may have been the intended quantity. 
Por 6 Cubos de Madera para subir mescla á I p[es]o 6

Por I2 bateas para lo mismo á $6 \mathrm{rr}[\mathrm{eale}] \mathrm{s} \quad 9$

Por Ioo p[eso]s que se regulan para comprar cuerdas para calabrotes, Barriles para acarrear agua, Pariguelas, Azadones y palas $\quad 100$

Por 5 Puertas que hay que hacer nueba con Marcos y Umbrales á I6 p[eso]s

$$
\text { Suma } \quad \frac{80}{5979.4}
$$

350 cartloads [Io9 cubic $\mathrm{m}=3850$ cubic feet] ${ }^{19}$ of stone delivered on site of the work and brought from the nearest rock quarry, at I peso each

355 cartloads $\left[80\right.$ cubic $\mathrm{m}=2840$ cubic feet ${ }^{20}$ of tierra blanca to make lodo [mud mortar] delivered to the same place at 4 reales each 2000 fanegas [I I cubic $\mathrm{m}=3920$ cubic feet] ${ }^{2 \mathrm{I}}$ of lime for concreting the azoteas [flat roofs], enjarres [plaster] and sarpeos [point] the walls inside and out, and whitewash them at 6 reales the fanega, delivered to the work 350 pesos 820 cartloads [I 85.7 cubic $m=6560$ cubic feet] of sand to make mortar, averaging 4 fanegas [0.22 cubic $m=8$ cubic feet] per each cart and 4 reales for each of these [cartloads] 520 morillos $^{22}$ for the replacement of the vigas of the roofs and soleras $^{23}$ at I peso each I6,995 tabletas $^{24}$ at 30 pesos the thousand

19. One cartload of stone was approximately 0.42 cubic $\mathrm{m}$ ( $\mathrm{s}$ cubic feet), according to the ratios of wall to cartload used in the appraisals of San Antonio mission buildings in the I 820 , but it appears that the carts used at the Alamo in I 8 I o were smaller. They could hold only about 0.22 cubic $\mathrm{m}$ ( 8 cubic feet) of sand or earth, and probably held about 0.3 I cubic $\mathrm{m}$ (I I cubic feet) of stone, which could be piled higher. See Ramón Músquiz and Miguel Arciniega, "Report of the appraisal and sale of Mission San José buildings", December I 8, I 823, Austin, Texas, Texas General Land Office, Spanish Archives, box I 22, file io, pp. I I4-i I6r.

20. See the listing for cartloads of sand, below.

21. One fanega equals 0.05 cubic m (I.96 cubic feet).

22. A morillo is a timber, a piece of wood for construction.

23. A solera is a piece of wood laid horizontally, on which are placed other pieces such as the rafters of a roof, vertically or at an angle - in this usage, it means the same as an estribo, a wall plate, a beam laid along the top of a wall to distribute the weight of the roof beams. However, it can also be used generically to mean a stringer, cross-beam, or rib.

24. Tabletas are small boards; in this case they are the same as latillas, boards placed between vigas to support a flat earthen roof. 
73 canales [roof drains] of wood at I peso each 600 days of labor of the Maestros at I 2 reales per day 3600 days of labor of the laborers at 3 reales per day 900 pesos I 2 cueros de res [cowhides] to make lashings and to tie together the I 350 pesos andamios [scaffolding] at 6 reales each 6 buckets of wood to raise the mortar at I peso each I 2 tubs for the same purpose at 6 reales each Ioo pesos assigned to buy cordage for cables, barrels to carry water,

handbarrows, picks and shovels 5 doors which have to be made new, with frames and doorsills,

at 16 reales each

Total $\frac{80 \text { pesos }}{5979 \text { pesos } 4 \text { reales }^{25}}$

The friary re-roofing project used many of the same structural components and materials proposed in the estimate for the completion of the church roof. The friary work required numerous cartloads of stone, earth, lime and sand, a large number of morillos and tabletas, and a number of canales and cueros de res. The uses of each of these materials were stated explicitly in the I 809 friary project. For example, the tierra was specifically tierra blanca, a white caliche soil, a clay with a high calcium content found everywhere in San Antonio, and it was to be used to make lodo, mud or adobe mortar as differentiated from lime mortar. The lodo would be used with the cartloads of stone to rebuild the walls needing to be replaced on the friary. The volumes indicated here are three parts of lodo to four parts of stone, a very high ratio.

The large quantity of lime was "para ormigones las azoteas, enjarres, y sarpeos las paredes [...] y blanquear las dichas", for concreting the flat roofs, plastering and pointing the walls, and whitewashing them. Wall plaster was typically a mixture of three parts sand to one part lime - this was the ratio used to plaster the church at Tumacácori, in southern Arizona, in the I820s, for example, and the same ratio was commonly used all over the Spanish new world during the colonial period. ${ }^{26}$ The amounts given here are three parts

25. Mariano Varela, comisionado del Hospital, to governor Manuel de Salcedo, May 5, I 809, BAM, 4I, pp. 207-208.

26. James E. Ivey, "Historic Structure Report, Tumacácori, Calabazas, and Guevavi Units, Tumacácori National Historical Park, Arizona”, manuscript in the files of Tumacácori National Historical Park, Tumacácori, Arizona, 2004; Sidney David Markman, Colonial Architecture of Antigua Guatemala, Philadelphia, American Philosophical Society, 1966, pp. 29-30; Mardith K. 
sand to two parts lime, suggesting that only about half the lime was to be mixed with the sand at a 3:I ratio for lime mortar — the other half of the lime was to be mixed with water and perhaps a small quantity of very fine sand to make white-wash for the final finish of the walls. The azotea, the flat roof, they stated, "deben echarsele de ormigon de mesclas", should be made of a concrete mortar - that is, lime mortar mixed with sand, gravel, and small stones. The walls needed to "sarpearse y enjarrarse con mescla" (be pointed and plastered with mortar).

The morillos were to "reponer la[s] vigas de los techos y soleras" (to replace the vigas of the roofs and the soleras), the latter being the wall plates forming support surfaces along the wall tops, because "las tableta[s] y vigas [estaban] podridas", the boards and vigas were rotten. The boards extended from viga to viga, forming the ceiling of the room and supporting the ormigon mixture that made the water-proof roof surface. The original flat, viga-supported roofs were being replaced with new ones of the same sort.

The roofing system used for the hospital was of the general category called alfarje, or wood-supported, as opposed to stone vaulted. ${ }^{27}$ The vigas rested on wall plates, wooden beams called estribos along the wall tops. In the estimate for the repairs to the hospital, these estribos were called by the more general term, soleras. These helped support the roof structure and spread its weight along the wall tops. The vigas were covered by the tabletas, extending from viga to viga to form the ceiling and to support the weight of the ormigon roof itself. New canales, or roof drains, were spaced along the wall, and can be seen in drawings of the building made in the I830s and I840s, demonstrating that the I809 re-roofing did indeed put a new flat, viga-supported roof on the hospital. ${ }^{28}$

\section{The Church Building in I 810}

The repairs to the Valero friary hospital were built over a one-year period, from I809 to I8Io. When this work was complete, Mariano de Varela proposed that a similar project be carried out to roof the church and put it into use as an

Schuetz (ed. and trans.), Architectural Practice in Mexico City: A Manual for Journeyman Architects of the Eighteenth Century, Tucson, University of Arizona Press, 1987, p. 23 and n. I 5.

27. Rafael López Guzmán et al., Arquitectura y Carpintería Mudéjar en Nueva España, Mexico City, Grupo Consorcio de Fabricaciones y Construcciones, I992, pp. 72-76.

28. William Bollaert, "The Alamo, I844", in Nelson, Illustrated History, p. 76. 
artillery storehouse. By the time the church roofing project was proposed in I8IO, the church had deteriorated somewhat from its condition in I793. For example, the plan accompanying the estimate to finish the roof of the church in I8Io does not mention a vaulted roof over the sanctuary of the church. This indicates that the vaulting had fallen in by $18 \mathrm{IO}$, about forty-five years after it had been built, but the rib at the mouth of the sanctuary remained in place. As a result, the sanctuary required a roof just like the rest of the church. The walls were apparently no higher than they were in I793, showing that the effort to finish the church had been given up by that time. The pendentives that were to support the cimborio, the drum under the dome, had been built in the period just before 1772 , probably by Estevan Losoya in $1765-1767$. They were not mentioned explicitly in the inventories, but the 1793 inventory said that the arcos torales (main transverse arches) were "ready to receive the cimborio", the drum that rested on the main arches and the pendentives to support the dome, suggesting that the pendentives were in place. The notations on the I8Io drawing made the presence of the pendentives clearer, saying that here were "pichinas que han de sentar las gualdras" (pendentives that are to support the gualdras), and that "los altos van cubiertos de Piedra hasta recibir las Gualdras" (the tops [of the pendentives] are going to be covered with stonework up to where they would receive the joists.) The pendentives filled the corners of the square area of the crossing of the transepts and nave, leaving an octagonal opening in the middle $7.6 \mathrm{~m}$ (25 feet) across - that the opening was octagonal is shown on the I8 Io plan drawing. Losoya had leveled this opening with its top about $2.3 \mathrm{~m}$ (7.5 feet) higher than the walls of the nave.

\section{The Proposal to Finish the Roof of the Church Building}

The project proposed by Mariano de Varela in I8Io was "cerrar interinam[en]te la Yglesia de Valero, con el obgeto de que sirva de Almacen de Artill[eri]a en term[in]o de conservar su buena fabrica acerbando de levantar sus paredes laterales" (to close the church of Valero temporarily, with the intent that it would serve as an artillery storehouse, in order to conserve the good fabric used for raising its side walls). ${ }^{29}$ The sense of the statement seems to be that the wooden roof would be only an interim covering for the building, that it would protect

29. Bernardo Bonavia to Nemesio Salcedo, May I6, I8 I o, BAM, 45, p. 240. 
the walls of the church, and allow its temporary use as an artillery storehouse, until such time that the vaulted roof could be completed. Presumably the building would then be used as a church, as was intended.

Comparing the I809 friary project materials list with the I8Io church roof project list makes it clear that the same general roofing system was intended for both structures. For example, both used morillos, soleras, tabletas, and canales; and both listed large quantities of lime, sand, stone, and earth, as well as hides for making lashings to fasten together the construction. However, the comparison of the materials lists also tells us that the roofing of the church would involve a more complex structure than the roof of the friary. Specifically, the church project included gualdras and cuartones - these massive timbers indicate that the church was to receive something more complex than the simple flat roof built on the friary.

Two elements of the church as built required that the roof for the building be more complex. These were the high arches of the nave, transept, and sanctuary ribs, standing well above the height of the completed parts of the walls, and the large octagonal opening where the transepts crossed the nave, twentyfive feet across. This large open area required a novel but delightfully simple solution for it to be roofed. This was a flattened, pyramidal roof, shown on the plan, that had to have some built-in slope to allow the roofing to be self-supporting, since at about thirty-three feet altitude it was too high to be supported by posts. Over the ribs of the bays of the sanctuary, transepts and nave, the roof was to be a low gabled structure. It was intended to be a strange hybrid, like a shingled gabled roof, but sealed with a thick layer of earth and plaster above the tabletas. Although the earth-covered roof required some slope so that rain would drain rather than forming puddles, none of these slopes could be steep.

The drawing by Everett shows that the entire wall area of the transepts and sanctuary stood about six or seven feet higher than the walls of the nave and façade, even after the demolition, remodeling, and destruction of the Battle of the Alamo. This indicates that the statement in the labels on the plan that the high areas at the tops of the pendentives, \#4, were $2.3 \mathrm{~m}(7.2$ feet) high meant that they were that much higher than the nave walls - this matches the height estimates I have made by direct examination of the surviving building fabric itself, examination of architectural drawings of the building made in the 1970s, and from comparison of this information with the Everett drawing. 
3. The sketch plan prepared as part of the I 8 Io estimate to roof the church of the ex-mission of Valero. This is the only known architectural drawing of a Texas mission in the Spanish colonial period. Drawn by master masons Juan Diego Veloz, Juan de Dios Cortez, and José Cayetano del Valle, April 25, I 8 Io.

Original in the Bexar Archives, microfilm roll 68:802, no date, University of Texas at Austin-Center for American History. Photograph: courtesy of the Center for American History, University of Texas.

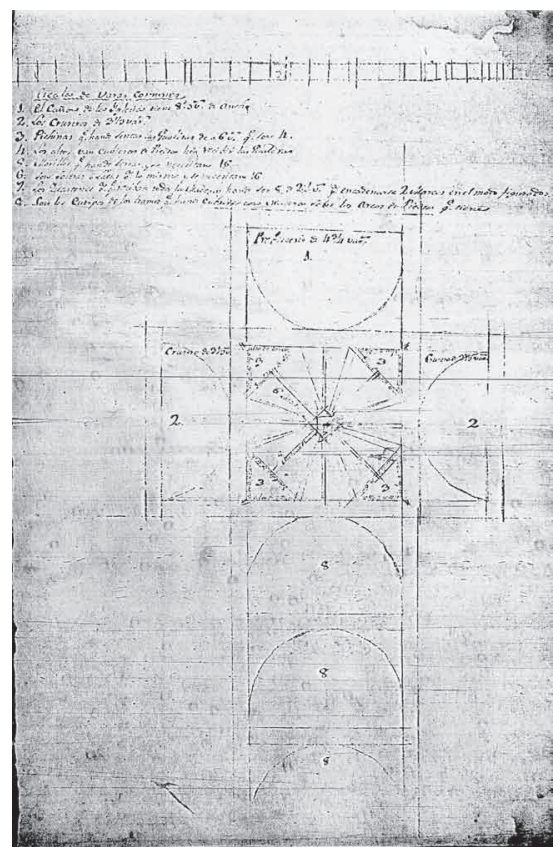

The sketch plan accompanying the estimate for the completion of the Valero roof indicates that the cimborio was to be octagonal rather than circular (fig. 3). The octagonal plan had been built up so that it was at level with the peaks of the ribs all the way around, and probably one vara thick, the thickness of the ribs. Because the pendentives had been built, the areas in the corners of the transept crossing above them had to have been leveled up at the height of the transept and sanctuary walls as well, and therefore were the same height as the peaks of the vault ribs. This would have formed an almost exactly level, square structure with an octagonal central opening.

The estimate lists the following materials to build this roof:

Por 258 Morillos de 6 var[a]s á i p[es]o 258

Por II Gualdras de id[em] á 4 p[es]os

Por i6 Morillos p[ar]a soleras á io r[eale]s

Por Io,60o tabletas á 35 p[es]os millar

Por 70 canales á I p[es]o

Por 522 faneg[a]s de Cal á i p[es]o 
Por 1566 id[e]m de Arena á I r[ea]l

Por el trabajo de 5 M[aes]tros Albañiles, y 25 Peones los primeros á

I2 r[eale]s diarios y los segundos á 4 r[eale]s en el termino de

60 dias en $\mathrm{q}[\mathrm{u}] \mathrm{e}$ se conjetura la conclusion de la obra

$\mathrm{I} 200$

Por Io cueros de res p[ar]a correas á 6 r[eale]s

Por 6 cubos de Madera p[ar]a subir mescla á I p[es]o

Por 22 bateas p[ar]a lo mismo á 6 r[eale]s

Por $50 \mathrm{p}[\mathrm{es}]$ os q[u]e se regulan p[ar]a comprar Barriles p[ar]a acarrear

Agua, Parihuelas, Azadones, y Palas

$$
\text { Suma } \quad \frac{50}{3000.4}
$$

For 258 morillos of $4.99 \mathrm{~m}$ (I6.4 feet) at I peso 258

For I I gualdras of the same size at 4 pesos $\quad 44$

For I6 morillos for soleras at Io reales $\quad$ I8

For 10,600 tabletas at 35 pesos the thousand $37 \mathrm{I}$

For 70 canales [roof drains] at I peso 70

For 522 fanegas [28.9 cubic $\mathrm{m}=\mathrm{I} 023$ cubic feet] of lime at I peso 522

For $\mathrm{I}, 566$ fanegas $[86.9$ cubic $\mathrm{m}=3069$ cubic feet] of sand at I real $\quad$ I95.6

For 324 carretas $[73.4$ cubic $m=2592$ cubic feet] of earth at 3 reales I 21.4

For $\mathrm{I} 28$ carretas $[39.8$ cubic $\mathrm{m}=\mathrm{I} 408$ cubic feet] of stone at I peso $\quad$ I 28

For the labor of 5 Master Masons, and 25 laborers, the first at

I 2 reales per day and the second at 4 reales, for 60 days, assumed

to be enough to finish the work

$\mathrm{I} 200$

For Io cow-hides for lashings at 6 reales

For 6 wooden buckets to take up mortar at I peso

For 12 tubs for the same at 6 reales

For 50 pesos alloted to buy barrels for carrying water, handbarrows, adzes, and shovels

Total 3000 pesos $4 \frac{50}{\text { reales }^{30}}$

The plan gives the sizes of the spaces in the church, as well as a general idea of how the critical roofing system over the nave/transept crossing would be constructed:

30. Juan Ygnacio de Arrambide, captain of the Compañía Volante, to commandant general Second Brigade Bernardo Bonavia, April 25, I8 Iо, Bam, 44, pp. 953-955R. 
I. El cañon de la Yglesia tiene $8 \mathrm{I} / 2$ v[ara]s de ancho

2. Los cruseros de $3^{\mathrm{I} / 2} \operatorname{var}[\mathrm{a}] \mathrm{s}$.

3. Pichinas $\mathrm{q}[\mathrm{u}]$ e han de sentar las Gualdras de a 6 v[ara]s q[u]e son 4.

4. Los altos van cubiertos de Piedra h[as] ta recibir las Gualdras.

5. Morillos q[u]e han de serrar, y se necesitan I6.

6. Son Soleras o Latas p[ar]a lo mismo y se necesitan I6.

7. Los Quartones p[ar]a q[u]e reciban toda la Madera han de ser 8 de 2 I $/ 2$ v[ara]s $\mathrm{p}$ [ar]a encadenarse 2 Marcos en el modo figurado.

8. Son los Cuerpos de los tramos q[u]e han de cubrirse con Madera sobre los arcos de Piedra q[u]e tiene.

I. The nave of the church is $8 \mathrm{I} / 2$ varas $[6.9 \mathrm{~m}=22.8$ feet $]$ wide. $^{3 \mathrm{I}}$

2. Transepts of $3 \mathrm{I} / 2$ varas $[2.77 \mathrm{~m}=9$. I feet in length $] .^{32}$

3. Pendentives (pichinas), that are to support the large joists (gualdras); each of the four joists is 6 varas $[4.99 \mathrm{~m}=\mathrm{I} 6.4$ feet] long.

4. The tops of the pendentives are going to be covered with stonework up to where they would receive the joists.

5. Beams (morillos) to close [the roof]; 16 are required.

6. These are crosspieces (soleras or latas) for the same purpose; 16 are required.

7. The large beams (cuartones) ${ }^{33}$ that receive all the timbers are to be eight, each $2 \mathrm{I} / 2$ varas [2.I $\mathrm{m}=6.9 \mathrm{feet}$ long, in order to be fastened together into two frames in the manner shown.

8. These are the forms (cuerpos) of the divisions (tramos) that are to be roofed with wood over the arches of stone, already built. ${ }^{34}$

The labels on the plan read:

I. Prebisterio [sic] de $43 / 4$ var[a]s

2. Crusero de $3 \mathrm{I} / 3$ v[ara]s

3. Gualdras de 6 v[ara]s

3I. The actual width is $6.88 \mathrm{~m}$ (22.6 feet) between the faces of the pilasters.

32. The real distance is $2.8 \mathrm{~m}$ (9.16 feet) on the west side of the south transept. The east side of this transept is $2.9 \mathrm{~m}$ (9.5 feet), and the north transept is $2.6 \mathrm{~m}$ (8.55 feet) on the east and $2.6 \mathrm{~m}$ (8.56 feet) on the west.

33. A cuarton is a major supporting joist. The term gualdra is generally used to mean the same thing.

34. Note that the lengths of the bays are not given. 
4. Alto de $23 / 4 \mathrm{v}$ [ara]s

5. Morillos [on the beams]

6. Latas [between the beams]

7. [marking the two nested squares at the center of the "dome."]

8. [marking the roof areas of the nave between pilasters and ribs.]

I. Sanctuary of $43 / 4$ varas $\left[3.96 \mathrm{~m}=\mathrm{I} 3\right.$ feet length]. ${ }^{35}$

2. Transept of $3 \mathrm{I} / 3$ varas $[2.77 \mathrm{~m}=9$. I feet length].

3. Joists (gualdras) of 6 varas $[5 \mathrm{~m}=\mathrm{I} 6.5 \mathrm{feet}]$.

4. Height of $23 / 4$ varas $[2.28 \mathrm{~m}=7.5$ feet height].

5. Beams (morillos).

6. Laths (latas).

7. [marking the two nested squares at the center of the "dome."]

8. [marking the roof areas of the nave between pilasters and ribs.] ${ }^{36}$

\section{Analysis of the Estimate and Plan}

Juan Diego Veloz, Juan de Dios Cortez, and José Cayetano del Valle prepared the plan drawing as a general guide to the mason's concept for the construction of the roof of the church, and to where the various parts in the materials list would be used. It showed the outline of the stone walls of the building and indicated the measurements of the walls. Most of its details and notes are concerned with the construction of the wooden roof over the crossing of the nave and transepts. These details are limited, and descriptive rather than specific. Since this analysis is of an estimate, rather than a built structure, we are going to have to use estimates of our own to work out the intended roof design (fig. 4).

The plan shows only four gualdras (\#3 on the plan shown in figure 3) being used, each $5 \mathrm{~m}$ (I6.5 feet) long, while the materials list includes I I. The plan shows that the four it lists were to go on the tops of the pendentives, leaving seven unaccounted for. These seven were probably to form the ridge beams between the ribs, and each would have been trimmed to various lengths, depending on the width of the particular bay over which it ran. The

35. The actual distance is $3.8 \mathrm{I} \mathrm{m}$ (I 2.5 feet).

36. Juan Diego Veloz, Juan de Dios Cortez y José Cayetano del Valle to Juan Ygnacio de Arrambide, April 25, I810, BAM, I68, p. 802. 
THE COMPLETION OF THE CHURCH ROOF

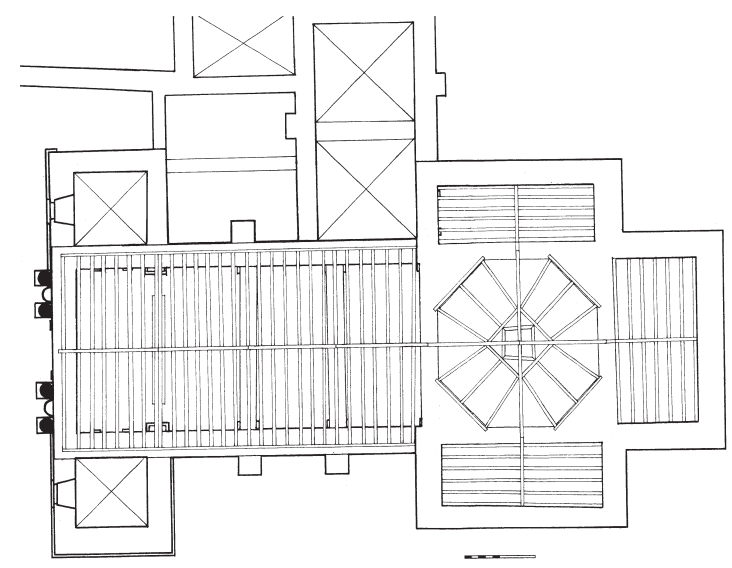

4. The reconstructed plan for erecting a wooden roof on the Valero church, based on an analysis of the estimate and sketch plan of I 8 I 0 . This plan shows only the primary beams of the suggested roof structure. Drawing by the author.

nave bays range from $4 \mathrm{~m}$ ( $\mathrm{I} 3$ feet Io inches) to $4.5 \mathrm{~m}$ ( $\mathrm{I} 4$ feet 8 inches) in width, from the center of one rib to the center of the next. The space between the ribs averaged about $3.8 \mathrm{~m}$ (I2.5 feet) of free span. Each ridge beam was to run from the peak of one rib to the peak of the next down the nave, or across the transepts and sanctuary. The ridge beams over the transepts would have been a little more than io feet long, and the one over the sanctuary would have been $3.96 \mathrm{~m}$ ( $\mathrm{I} 3$ feet) long. These would have been set into holes carved into the end walls of the sanctuary and transepts at one end, and rested on the arco toral ribs at the other end. Four bays or tramos in the nave, two transepts, and the sanctuary, gives seven sections needing these ridge beams.

The 258 morillos, each $5 \mathrm{~m}$ ( 16.5 feet) long, were to supply a number of components for the roof. The number of morillos included in the list of materials was an estimate of the number needed to build the roof and scaffolding, with a few extra included to allow for breakage. Four of them would be cut into sections to form the quartones (\# 7 ), and then assembled to form the central double square frame of the roof over the crossing. Another I6 were to form the rafters, (\#5), of the central roof over the transept crossing. This left 238 morillos that were to form the rafters of the sections of the church roof and the scaffolding. 
In order for the rafters of the roof to give effective support over a span averaging $3.8 \mathrm{~m}$ (I2.5 feet), the morillos would have had to be substantial, probably at least $7.62 \mathrm{~cm}$ ( 3 inches) thick by $22.86 \mathrm{~m}$ (9 inches) high. They would have extended from the central gualdra, or ridge beam, down to the side walls of each section, and been set on edge. Assuming that all the morillos were used for rafters, then they would have been set at about I I-inch centers and the roof would have required about 200 morillos. As the counts work out for the actual sizes of the roof plan, the estimated 258 morillos would have allowed about I6 extra for losses through damage during construction. However, this is unnecessarily close - the rafters would more likely have been set at about two-foot intervals. This would have used about I 2 rafters, leaving about I 46 morillos for scaffolding and loss through breakage (fig. 5).

If the cost of the beams were based on their size, and the morillos, at $7.62 \mathrm{~cm}$ ( 3 inches) by $22.86 \mathrm{~cm}$ ( 9 inches), were one peso each, then the gualdras of the same length and costing four pesos each would be about four times the size, or $30.5 \mathrm{~cm}$ (I2 inches) high by $22.86 \mathrm{~cm}$ (9 inches) thick, easily large enough to span up to $7.6 \mathrm{~m}$ (25 feet) without significant sag in the middle - in fact, this is the usual size for vigas over the naves of the seventeenth-century churches of New Mexico, which ranged up to $\mathrm{I} 2.2 \mathrm{~m}$ (40 feet) across. ${ }^{37}$ If the ridge beams were about $30.5 \mathrm{~cm}$ (I2 inches) high, they could rest directly on the peak of the ribs. This would give enough clearance so that the rafters of morillos could be set with a slope of about 8.5 degrees while clearing the shoulders of the ribs.

As was the case in the friary project, the tabletas were small boards used as latillas, set on top of the morillos and extending at right angles from one morillo to the next. They would have completely covered the roof surfaces of the bays, and were to support the earth of the flat roof. The roof area of the church was 290 square $\mathrm{m}$ (3 I 24 square feet). Assuming that the 10600 tabletas were about $60.96 \mathrm{~cm}$ (24 inches) by Io $\mathrm{cm}$ (4 inches) (and perhaps $2.54 \mathrm{~cm}$ [an inch] thick) each would have covered about 0.06 square $\mathrm{m}$ (0.67 square feet). Such a size would have required 4663 tabletas to cover the roof, leaving 5937 tabletas extra. Perhaps the roof was to have a double layer of tabletas for extra strength - if so, I 274 would be left over for breakage and probably to be used on the scaffolding.

37. James E. Ivey, In the Midst of a Loneliness: The Architectural History of the Salinas Missions, Santa Fe, National Park Service, Southwest Cultural Resources Center, Professional Papers, I988, vol. I 5, p. 49. 
THE COMPLETION OF THE CHURCH ROOF

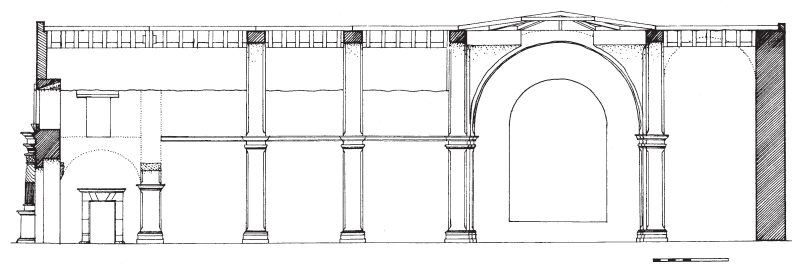

5. Section down the length of the Valero church, showing the suggested roof design based on the I 8 I o estimate and plan. Note that the vaulting over the apse, built in the 1760 s, has fallen in by this date. Drawing by the author.

Onto these boards, the cartloads of earth would have been spread. The large quantity of earth hauled to the site, 73.4 cubic $\mathrm{m}$ ( 2592 cubic feet), was poured onto the tabletas. This amount of earth was enough to cover the roof area of the church, 290 square m (3 I 24 square feet), to a depth of about $25.4 \mathrm{~cm}$ (Io inches).

The morillos would have been held to the central ridge beam by rawhide lashings, rather than iron nails, and the tabletas would have been tied to the morillos in the same way. These lashings would have been cut from the ro cowhides. If the typical useable area of a hide was about $1.52 \mathrm{~m}$ ( 5 feet) by $1.82 \mathrm{~m}$ ( 6 feet), and the strips cut were about $0.6 \mathrm{~cm}(\mathrm{I} / 4 \mathrm{inch}$ ) wide, then each hide would have supplied $439 \mathrm{~m}$ (I 440 feet) of cordage, or $439 \mathrm{~m}$ (I4400 feet) for the Io hides. This is about $4.4 \mathrm{~km}$ ( $23 / 4$ miles) of rawhide cordage, easily enough to tie together the roof structure and any scaffolding needing to be built.

There had to have been some provision to finish the front rib above the choir loft. However, the plan drawing ends at the bottom at the point where the rib over the choir loft would have been shown, if it had existed. It is not clear whether the drawing had originally continued the full length of the building, and had been torn at this point, or if it had originally ended here. Checking the measurements of the other tramos suggests that if anything had been drawn at the location of the choir rib, such as if a substitute of vigas had been shown, at least the edge of it would have shown on the portion of the drawing we have - indicating that the drawing did not address this problem area. This is undoubtably because the answer was simple and needed no particular drawing to show it, and therefore had no need to extend any farther towards the front of the building. 
With a width of only $7.6 \mathrm{~m}$ (25 feet), it would have been easy to replace the missing rib with a doubled morillo A-frame (fig. 6). The roof was generally to be constructed as a parhilera roof, where the rafters (pares) supported the ridge beam, the hilera. The outer ends of the pares were fixed on estribos or soleras, as in the friary hospital roof. These soleras rested on the tops of narrow stone walls built up on the massive walls of the church, using the 128 cartloads of stone. The arched stone ribs built in the 1760 o helped support and stabilize this structure, allowing it to be flatter than was typical of such a roof, but they were not really necessary to hold it up. In the area of the missing rib, doubled pares, using six morillos, four on each end of the gualdras meeting at this point, and probably two more morillos used as cross-beams, or nudillos, running from morillo set to morillo set as shown in figure 6, would have provided all the support and stabilization needed in this area.

Fourteen of the morillos would have been used as soleras, wall plates along the tops of the side walls of the bays of the nave, and along the sides of the transepts and sanctuary. Since the nave walls were to be raised about seven feet as part of the construction, these soleras could easily be put in place as part of that construction. To place them in the transepts and sanctuary would be a different problem - slots would have to be carved into the already-built side walls to accommodate them.

A separate listing of I6 morillos for "soleras, or latas", at Io reales each, indicates that they were of a different size than the morillos in the first group. These were to form the latas on the central roof, to carry the tabletas across the wider gaps of the rafters in this area. These latas would be thinner and wider than the morillos for the main roof areas - two inches by five inches would be a good size for them, and they would have to be about 20 feet long. These, cut into sections of various lengths, would be laid across the central roof rafters at intervals of about I I inch centers, and then the tabletas laid at right angles across them, edge to edge.

The $\mathrm{I} 28$ cartloads (about 39.8 cubic $\mathrm{m}=\mathrm{I} 408$ cubic feet) of stone would be used to build up the side walls of the nave about 2.I $\mathrm{m}$ (7 feet), and a similar increase at the front of the church above the façade. A gabled end wall of stone would have been built at the top of the façade, producing a silhouette something like the later familiar façade of the Alamo as built by the U.S. Army in I850, although the I8Io version would have been much lower and flatter. These side and front walls were about 148 linear feet of wall, which would give about 96.2 square $\mathrm{m}$ (I 036 square feet) of wall surface. The 39.8 cubic m (I 408 cubic 
6. Cross-section of the nave of the Valero church at the springers of the choir loft support rib, showing the components of the suggested roof.

Drawing by the author.

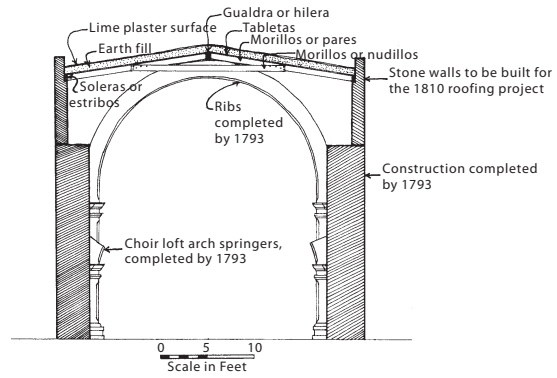

feet) of stone, plus about $15 \%$ for the lime mortar used to hold it together, or 3.9 cubic $\mathrm{m}$ ( 140 cubic feet) of lime, gives a total available volume of material of about 43.8 cubic $\mathrm{m}$ (I 549 cubic feet). This volume would give a wall thickness of about $45.7 \mathrm{~cm}$ (I.5 feet).

The proportions of the supplied amounts of lime and sand indicate a mixture of three parts sand to one part lime, the traditional ratio. The materials would make 2088 fanegas of sand/lime plaster. This is I I 5.8 cubic m (4092.5 cubic feet) of plaster, and would cover $304 \mathrm{I} .5$ square $\mathrm{m}$ ( 32740 square feet) of surface with several coats of mortar totaling $3.8 \mathrm{I} \mathrm{cm}$ (I.5 inches) thick, the typical thickness of a mortar surface layer. There was only about $1486.4 \mathrm{~m}$ (I600o square feet) of wall surface on the church, inside and out, so about half the plaster was needed for that, leaving about 59.4 cubic $\mathrm{m}$ ( 2 Ioo cubic feet) of mortar. About 3.9 cubic $\mathrm{m}$ (I 40 cubic feet) would be needed to build the walls, leaving about 55.5 cubic $\mathrm{m}$ ( 960 cubic feet). This would coat the roof $19 \mathrm{~cm}$ (7.5 inches) thick if spread evenly. Both the earth and plaster surfaces would have been sloped and shaped so as to facilitate drainage, and the plaster would make the final seal to prevent leakage, especially along the line where the roof met the stone side walls.

Drainage for the new roof was to be provided by the 70 canales included in the list of materials. This would suggest Io canales for each section of the roof, or five for each side of the four bays of the nave, the two transepts, and the sanctuary. This would put a canal about every three feet along the tops of the walls.

\section{Scaffolding}

Scaffolding, in spite of its importance to a construction project, is a little-studied topic, probably because it is not as attractive as the building 
itself. ${ }^{3}$ However, the complexity of the scaffolding added expense to a project, and there seems to be a direct relationship between this complexity of the required scaffolding and centering and the cost of a building. If the reader would imagine a vaulted church, not in terms of the stone of its structure, but in terms of the webwork of wooden scaffolding and centering needed to raise, assemble, hold in place, and finish the church, he or she will begin to see the implications of this. The wooden scaffolding and centering is the dynamic part of a construction project. Any chance we get to see scaffolding in use, as on the Valero friary hospital re-roofing project in $\mathrm{I} 809$, is worth some attention. The Alamo church re-roofing estimate does not specifically mention scaffolding, but because of the nature of the project, it had to use it. This was a roofing project, rather than a masonry construction project, so the scaffolding needed would have consisted largely of a central structure under the "dome" at the crossing of the transepts, where the most complex construction and interim support was to take place. In the nave, transepts and sanctuary, the much more limited scaffolding would have served principally as a means of reaching the wall and rib tops, which would have been wide enough for the work-crew to move around on. The workmen would have set up lifting equipment on the wall tops, in the form of winches or a pulley system. These would have lifted the large beams, and buckets of stone, mortar and plaster, to the roof level. A large range of choice in this lifting equipment would have been available, from compact winches used to move and lift artillery to shear legs and small cranes of various designs.

Some of the scaffolding would have been either portable or easily set up and taken down. This would have been used to allow the plasterers to reach all the wall surfaces of the church, inside and out.

\section{Why the Project Was Not Carried Out}

On April 25, when he forwarded the proposal with its plan drawing and estimate of materials to vice-commandant general Bernardo de Bonavia, Ignacio

38. Few New World Spanish colonial scholars discuss scaffolding. One of the few mentions I could find was a discussion by George Kubler, in Mexican Architecture of the Sixteenth Century, 2 vols., New Haven, Yale University Press, 1948, where he described some of the practices of centering and scaffolding in sixteenth-century Mexico in vol. I, pp. I73 and I83. 
Arrambide added a note at the end of his letter suggesting that it would be possible to do the work at a much lower cost if the carts and oxen were taken from the herds and equipment of the army, the wood was cut and the lime was burned by the troops, if the work was done on an irregular schedule, and if the laborers were paid no more than Io pesos per day total, rather than the I2 pesos four reales (25 laborers at four reales a day each) proposed by the masons. ${ }^{39}$

On May 2, Bonavia sent a revised evaluation of the work to the commandant general, Nemesio Salcedo, using the cost-cutting suggestions proposed by Arrambide. The revised proposal is not presently available to us, but a copy may eventually be found in the Saltillo Archives. Bonavia considered that the government would benefit from the closing of the church roof, and "because of the reasonable distrust that I have of the skill of the evaluators", he had made the revised estimate: "the work could proceed more cheaply" using the government's oxen, carts, lime, and tools, and would be carried out "more easily, simply, and more quickly." He awaited Salcedo's decision, any changes he might wish to suggest for the project, and the authorization of the money to fund it. ${ }^{40}$ Two weeks later Bonavia sent a follow-up letter, wherein he stated: "I hope for your decision and that you might be pleased to return the evaluations to me."4I

It is clear from these references that Bonavia was in favor of the project to finish the roof on the church, and was waiting for final approval of the project and the funding from commandant general Salcedo. I have yet to find any indication that this approval was ever received. For now, at least, we must assume that the project was never carried out, and the Alamo remained unroofed until the Battle of the Alamo in 1836, when colonel Ugartechea removed the rib structure and some upper walls. Finally, in I85I, the U.S. Army roofed the building to serve as a Quartermaster storehouse. The wooden raftered roof, built by the architect John Fries in 1850, was somewhat similar to the roof proposed by Veloz, Cortez, and Barrera, but was a steeper-sloped gabled roof with shingles rather than an earth and plaster surface. To cover the ends of the gables, the Army built the distinctive top to the façade that forms the familiar image of the Alamo as it is known today.

39. Juan Ygnacio de Arrambide, captain of the Compañía Volante, to commandant general Second Brigade Bernardo Bonavia, April 25, I8 Io, BAM, 44, pp. 953-955v.

40. Bernardo Bonavia to commandant general Nemesio Salcedo, May 2, I8 го, BAM, 45, pp. 36-37.

4I. Ibidem, May i6, i8 го, вам, 45, p. 240. 


\section{Conclusions}

In addition to the curiosity factor that these documents have, in that they deal with the notoriously famous Alamo - the "Shrine of Texas Liberty", as it is called in Texas - they are valuable to both the study of the architectural development of the buildings of mission San Antonio de Valero and what they tell us about the construction methods and creativity of the architects and carpenters working on the northern frontier of New Spain in its last years.

The details recorded on the diagram accompanying the estimate for the proposed roof of the Valero church both confirm earlier conclusions I had reached about the condition of the church when work stopped on the building about I772, and add more information about how far that work had been carried, information overlooked in the 1772 and 1793 descriptions of the church. It also tells us the condition of the structure in I8Io, only 26 years before the Battle of the Alamo that had such a devastating effect on the mission's surviving buildings.

Comparing the estimate prepared by the master masons with other documented construction projects in south Texas during the eighteenth century, we find that the methods did not change significantly through the eighteenth and early nineteenth centuries, and were not significantly different from the construction methods used to build the large mission churches still standing in San Antonio today. This was because building technology did not change significantly during this period, and the church, military, and civilians used the same builders. One result of making the comparison of work carried out by these various institutions is the realization that the expectations of each were different - that is, the Franciscans strove for stone vaulted buildings that could be expected to last with low maintenance costs for some time, while the military was willing to accept a roof with a far lower expected life of use. This is an indication of the difference in "mechanical culture", the attitudes towards necessary architecture and its purposes, between the two. The similarity between this decision on the part of the Spanish military for the roofing of Valero and the later actual armadura shingled roof actually built on the Valero church by the American army in $185 \mathrm{I}$ is obvious, and again indicates the similarity in mechanical culture between the two military organizations. The roofing of the church with a concrete vault in the I930s by the Daughters of the Republic of Texas, when it began to be called the "Shrine of Texas Liberty", again demonstrates the similarity in attitude 
towards structures of reverence between the Catholic Church and the secular Daughters. ${ }^{42}$

The only major variation was in the builders themselves — an imaginative builder could come up with something new using the same old techniques and materials. The striking octagonal "dome" proposed for the roof of the crossing of the transepts of the Alamo church was one such imaginative solution to a standard problem. The structure the master masons proposed is unique. I have never encountered a building on the northern frontier with such a combination of armadura and terrado - that is, the use of a rafter-supported roof that was finished with an earth and lime plaster surface rather than shingles or tiles. Similar low-angle wooden domes may be found in the far north; for example, the side chapel of San Miguel Arcángel de Moctezuma, in Sonora, had a low dome of this sort, and the nave of the church is roofed with rafters above stone ribs. However, in this case the rafters extended from rib to rib down the length of the nave, and both the roof of the nave and the side chapel had been finished with tiles rather than terrado. ${ }^{43}$

In spite of the misgivings of the military concerning the estimates for the cost of the project, the creativity of maestros Juan Diego Veloz, Juan de Dios Cortez, and José Cayetano del Valle give this little, uncompleted project on the far northern frontier in San Antonio, Texas, a special interest for architectural historians. \&

42. My thanks to the anonymous reviewer for the suggestion of the idea of "mechanical culture" as an index of institutional difference between the church and the military.

43. Jorge Olvera H., Finding Father Kino: The Discovery of the Remains of Father Eusebio Francisco Kino, S.J., 1965-1966, Tucson, Southwestern Mission Research Center, I 998, pp. I I 5-I I 6 and figs. 18 and 20 following p. 90. Olvera suggests that the dome over the side chapel at San Miguel numbers off the churches he built in the first decade of the eighteenth century across Sonora. 